This paper reports comparative tribotechnical tests of surfaces, hardened by cementation and plasma nitriding Avinit N, for contact fatigue strength at friction in rolling with slipping. Following the cementation, the samples' hardened layer thickness was $1.2 \mathrm{~mm}$; on nitriding, the thickness of the hardened layer was $0.25 \mathrm{~mm}$. The tests were carried out using an acoustic emission method, which is extremely sensitive when registering the transition of tribosystems' operation from the normal (mechanochemical) wear to the initial surface destruction of a fatigue nature.

The tests have shown that the average number of cycles before the initial destruction due to fatigue for the samples hardened by the Avinit nitriding technology is 1.82-time higher compared to the cementation-hardened samples. The depth of damage at the surface of the cemented samples could vary between 0.01 and $0.027 \mathrm{~mm}$ depending on the diameter of the damage. For the nitrided surfaces, the depth of damage did not exceed $0.003 \mathrm{~mm}$.

The samples' resistance to the fatigue wear (destruction) was determined by tests based on 1,000,000 cycles at contact loads $\sigma_{\max }=1,140 \mathrm{MPa}$, typical of medium-loaded surfaces. The test results demonstrated that the integrated multicyclic resistance to fatigue wear (destruction) of the samples, hardened by nitriding, is more than 10 times higher than that of the cementation-hardened samples.

The study reported here confirms the effectiveness of using the Avinit ion-plasma nitriding technology instead of cementing, to improve the contact strength of the parts' surfaces. At the same time, worth noting are the advantages of this technology to maintain the size and high quality of surface treatment, which eliminates the need to mechanically finish them after hardening

Keywords: friction; rolling with surface slipping, contact fatigue strength; gas cementation; plasma nitriding

Received date 30.09.2020

\section{COMPARATIVE ANALYSIS OF THE FATIGUE CONTACT STRENGTH OF SURFACES HARDENED BY CEMENTATION AND THE ION- PLASMA NITRIDING AVINIT N}

A. Sagalov ych

Academician of Academy of Technological Sciences of Ukraine, Head of Department

Department of Special Technologies*

E-mail: int@kharkov.ua V. Popov

$\mathrm{PhD}$, Academician of Academy of Technological Sciences of Ukraine, Chairman of the Management Board*

E-mail: fed@fed.com.ua

V. S a galov y c h

Doctor of Technical Sciences, Professor, Academician of Academy of Technological Sciences of Ukraine, Director

NTC «Nanotechnologie»

Myru blvd., 3, Kharkiv, Ukraine, 61108

E-mail: avinit@avinit.ua

S. D u d n i k

$\mathrm{PhD}$, Head of Department Department of Fine Technologies*

E-mail: dudnik@avinit.ua

V. B o gos I a vze v Lead Designer*

E-mail: fed@fed.com.ua

M. S t ad n i chenko

$\mathrm{PhD}$, Associate Professor, Head of Laboratory Ivan Kozhedub Kharkiv National Air Force University Sumska str., $77 / 79$, Kharkiv, Ukraine, 61023

E-mail: info@hups.mil.gov.ua

A. E d i n o v y c h Lead Designer

SE Ivchenko-Progress

Ivanova str., 2, Zaporizhzhia, Ukraine, 69068

E-mail: belous@ivchenko-progress.com

*JSC «FED»

Sumska str., 132, Kharkiv, Ukraine, 61023

Copyright (C) 2020, A. Sagalovych, V. Popov, V. Sagalovych,

S. Dudnik, V. Bogoslavtsev, M. Stadnichenko, A. Edinovych

This is an open access article under the CC BY license (http://creativecommons.org/licenses/by/4.0)

\section{Introduction}

The operation resource of parts in different devices, assemblies is in many cases determined by the capability of the material to withstand the fatigue destruction of working surfaces, which is characterized by such a quantity as the contact strength of the material.

It is known [1,2] that contact strength, in a general case, can be improved by reducing mechanical and thermal influences on contact surfaces due to their deformation and 
friction. Conventionally, this task is solved by increasing the hardness of contact surfaces, the use of anti-friction coatings and lubricants.

The methods that are applied to improve the contact strength of materials include common chemical-thermal techniques of cementing the surface of materials. Nitriding methods are also employed to increase the contact strength of materials, albeit to a lesser extent than cementation [3-5]. The latter is largely due to conventional ideas about the advantage of cementation compared to nitriding in the formation of hardened layers of great thickness as its value affects an increase in the contact strength. This is probably due to the limited amount of research into the impact of nitriding on the value of the contact strength of materials.

The cementation implies a hardening with the simultaneous accumulation of energy at the boundary of the grain section, which further leads to the growth of microcracks. In addition, the release of energy in the contact interaction of surfaces leads to their heating and the destruction of carbides in the cemented layer, resulting in the decreased contact strength.

As regards nitriding, it is expected that the cessation of external influence would lead to a rapid restructuring of the structure, and, therefore, to the relaxation of residual stresses. This is the basis for tribotechnical tests for the fatigue of the contact strength of the surfaces hardened by cementation and nitriding, and for comparing the effectiveness of their use to improve the contact strength of materials.

Acquiring such information is important when choosing the chemical and thermal methods of materials treatment both to achieve certain indicators of their properties and to determine the conditions for their optimal application.

\section{Literature review and problem statement}

Being a method for improving the operational characteristics of materials, nitriding is increasingly common and, in many cases, can replace cementation and through-hardening.

Work [6] shows that the ionic nitriding of steel $35 \mathrm{CrMo}$ with a hardened layer of $0.4-0.5 \mathrm{~mm}$ thick can be used for heavy gears with contact stresses of up to $950 \mathrm{MPa}$ as an alternative to hardening the surface with cementation. By analyzing the causes of destruction of a cemented drive gear made of steel $18 \mathrm{NiCrMo5}$ UNI 7846, the authors of paper [7] suggested that the use of nitriding instead of cementation may resolve the issue related to the destruction of such a gear. Based on the experimental data from various literary sources, the authors of [8] analyzed the impact exerted by various methods of nitriding on the cyclical strength of structural steels. They concluded that regardless of the nitriding methods, the characteristics of multicycle fatigue of structural steels improve. At the same time, the effectiveness of nitriding aimed at improving fatigue strength depends on many interrelated factors (the process technology, the chemical composition of steel, etc.). Paper [9] examines the patterns in the formation of the structure of steels and alloys at nitriding and their effect on hardness, durability, and contact endurance. The authors of the cited paper believe that nitriding can be used to strengthen highly-loaded toothed gears with contact endurance comparable to the contact endurance of cemented toothed gears. In this case, the labor-intensity of their manufacture can be reduced by
$2-30 \%$ by excluding the tooth grinding process. Work [10] reported a study to compare the fatigue endurance of cemented and nitrided gears for industrial use, which showed that nitriding can compete with cementation processes in the manufacture of gears.

Over the last decade, the researchers' attention to the methods of nitriding has been increasingly attracted to the methods of ionic (plasma) nitriding. This is because these methods demonstrate significant differences and advantages over other conventional methods, in particular, furnace methods of gas nitriding $[3,5]$, namely:

- a significant reduction (by $2-3$ times) in the duration of diffusion saturation with nitride of the surface layer of alloys based on iron at a total decrease in the processing cycle time of up to $3-5$ times;

- they make it possible to completely avoid hydrogen fragility;

- they ensure retaining the size (nitriding "to size") and high quality of surface treatment, a reduction in the fragility of the nitrided layer, and formation of nitride zones of all compositions without pores, thereby eliminating the need to refine the surface after nitriding.

The use of conventional methods of gas nitriding often requires very time-consuming, complicated operations of high-precision mechanical grinding, such as in the manufacture of parts for high-precision toothed gears. At the same time, due to the formation of a fragile nitride layer, it is necessary, at times, to sand it to a depth of $0.1 \mathrm{~mm}$, which can make up a significant part of the entire hardened layer and, as a result, a significant deterioration of mechanical characteristics.

Based on the analysis of working conditions of open toothed gears, the authors of [11] demonstrated the effectiveness of using advanced technologies of surface hardening by ion nitriding methods in order to increase the gears' durability. Work [12] reported a study into the contact endurance of samples made of steel X12M, which were exposed to various kinds of heat treatment and ion nitriding. It is established that the durability of steel X12M depends on the conditions of heat treatment and ion nitriding, which can be optimized according to certain criteria. The dependence of the properties of martensitically aged steel (brand 250) after ion nitriding in order to establish optimal conditions of nitriding was investigated in paper [13]. Work [14] investigated the effect of ion nitriding on the fatigue properties of steel AISI 4340. It is shown that ion nitriding achieves an increase in the fatigue strength of steel of $91 \%$. Study [15] analyzes the peculiarities of ion nitriding technology. In particular, it is noted that the gears exposed to ionic nitriding do not need such large thicknesses of the hardened layer as is the case at cementation. An important advantage in the ion nitriding of steel toothed gears is the formation of a nitrided layer with a well-controlled structure at relatively low temperatures. That makes it possible to use the process as a final operation, which reduces production costs. The cost of machining standard toothed wheels in the industrial process often exceeds $55 \%$ of the total cost, especially if the cementation of toothed wheels requires considerable grinding. The comparative analysis of the applied technologies for the chemical and thermal treatment of toothed wheels and other parts of aircraft engines based on the technique of hardening working surfaces that determine the durability of operation was also reported in work [16]. 
Our analysis of the scientific literature reveals that the effectiveness of nitriding application to increase the fatigue contact strength of surfaces, as well as other characteristics of materials, depends on the material, the nitriding technique, and the operating conditions of the material. The patented techniques of plasma precision nitriding Avinit N [17, 18] are industrially used at the enterprise AT "FED" (Ukraine). The current stage of research and development necessitates further accumulation of experimental data on this issue, their analysis, and generalization. It is expedient to test the fatigue contact strength of surfaces, hardened by cementation and the ion-plasma nitriding Avinit N, both in terms of acquiring new experimental data in this field and the practical implementation of the devised methods.

\section{The aim and objectives of the study}

The aim of this study was to compare the effectiveness of using a plasma nitriding method based on the Avinit $\mathrm{N}$ technology and the conventional gas cementation technology, in order to improve the contact strength of medium-loaded $\left(\sigma_{\max } \approx 1,000 \mathrm{MPa}\right)$ surfaces. This would make it possible to acquire the information that is necessary for the reasonable choice of the method of surface hardening, including, based on the Avinit plasma nitriding technology.

To accomplish the aim, the following tasks have been set:

- to perform accelerated tests to determine the time when the surface of the examined samples manifests the initial destruction of a fatigue nature;

- to determine the resistance of the compared samples to fatigue destruction based on $1 \cdot 10^{6}$ cycles in prolonged tests.

\section{The equipment, materials, and procedures used in friction and wear tests}

To register the onset of the process of fatigue destruction over a relatively short time during testing for contact strength, scientists from the Ivan Kozhedub Kharkiv National Air Force University modernized the friction machine 2070 SMT-1. Improvements implied increasing the amount of load that can be applied to samples by changing the fastening of the carriage lever and automating the load change process. That made it possible to increase the maximum long-acting load amount from 1,600 N to 4,500 N [19]. Rubbing surfaces were lubricated by the lubricant M-8B, GOST 10541, by immersing a lower sample into the lubricant, which helped avoid an unacceptable overheating of test samples and lubricant environment during the test cycle. The temperature in the contact area was measured by the 760 Nymbus-760 pyrometer.

For the samples studied, contact stresses due to the absolute load $P=4,500 \mathrm{~N}$ were determined from the Hertz formula. During the test, we registered the moment of friction, which was converted to the friction coefficient $\left(f_{\text {fric }}\right)$.

To register the number of cycles before the beginning of fatigue destruction, as is customary in the fatigue tests of structural materials, we used an acoustic-emission information-diagnostic system whose principles are set out in $[19,20]$.
Acoustic emission power was used as an informative parameter of acoustic emission, which was evaluated in relative units. Acoustic emission signals were registered throughout the entire test time. The number of cycles before the beginning of fatigue damage was determined by the condition one spin equals one cycle.

The use of the acoustic emission method is an effective tool for accelerated tests because it is extremely sensitive when registering the transition of tribosystems from the normal (mechanochemical) wear to the initial surface destruction of a fatigue nature.

The test objects were samples, standard for the friction machines SMC-2 and 2070 SMT-1, in the form of disks with a diameter of $50 \mathrm{~mm}$ and a height of $12 \mathrm{~mm}$, which were made from the heat-resistant steel 20X3MVF, GOST 20072. The grade of the material was chosen from the condition that this steel can be hardened by both cementation and nitriding.

Two groups of samples were prepared for the tests. One group included four pairs of samples hardened by the conventional gas cementation technology implying the surface grinding after hardening. The second group included four pairs of samples hardened by the Avinit N nitriding technology devised by the joint-stock company "FED" (Ukraine) without machining the surface after hardening.

The thickness of the cementation-hardened layer, according to the metallographic study of the samples, was $1.2 \mathrm{~mm}$, the nitrided layer $-0.25 \mathrm{~mm}$. The surface hardness HRN15 of the cemented and nitrided samples was, respectively, 89-90 and 90-91.5; the core hardness HRC - (34.5-36) and (27-28.5). Fig. 1, 2 show the microphotographs of thin sections with the structure of layers hardened by cementation and nitriding.
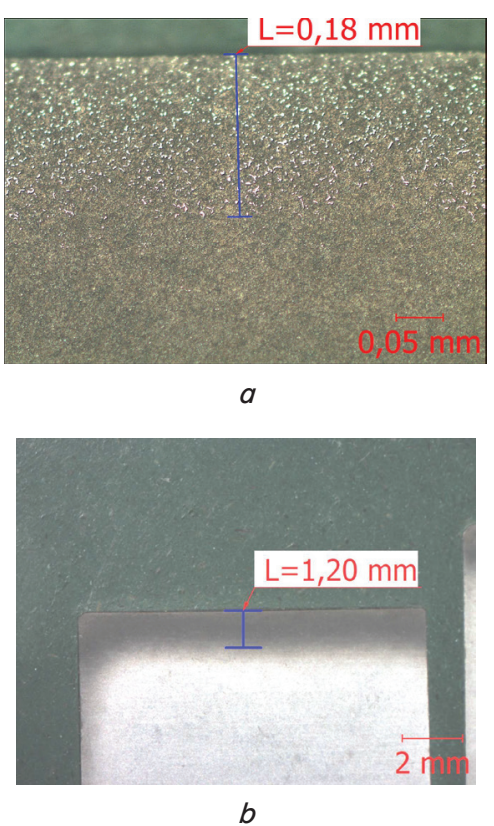

Fig. 1. The etched thin section of the sample hardened by cementation: $a$ - microphotograph; $b$ - macrophotograph

The microstructure of the cemented layer represented martensite and carbides: from the surface, to a depth of $\sim 0.18 \mathrm{~mm}$, carbides were larger, of the rounded and columnar shape; further, across the layer cross-section, finely-dis- 
persed carbides. The microstructure of the core represented the low-carbon martensite of steel 20X3MVF-SH, thermally treated to the appropriate hardness.

The results from determining the micro-hardness and effective depth of the layer corresponding to a micro-hardness of $500 \mathrm{HV}$ are given in Table 1.

The microstructure of the nitrided sample contained a surface layer of $\sim 0.01 \mathrm{~mm}$ thick, which, according to the $\mathrm{X}$-ray structure analysis, consisted mainly of $\gamma-\mathrm{Fe}_{4} \mathrm{~N}$. Further along the cross-section of the nitrided layer, the microstructure represented the tempering nitrogen martensite and thin excess nitrides.

The microstructure of the core is the tempering martensite of steel 20X3MVF, thermally treated for the corresponding hardness. Table 2 gives these micro-hardness values along the cross-section of the nitrided layer on samples No. $1 \mathrm{~A}$ and No. $5 \mathrm{~A}$.

The tests involved 4 pairs of samples indexed "C" (cementation/cementation) and 4 pairs of samples indexed "A" (nitriding/nitriding). The test scheme is "disk-disk".

Test conditions:

- drive sample rotation speed, $500 \mathrm{rpm}$;

- slipping between samples, $20 \%$;

- absolute load, $4500 \mathrm{~N}$ (estimated specific contact load,

$\sigma_{\max }=1,140 \mathrm{MPa}$ ); loading speed, $450 \mathrm{~N} / \mathrm{s}$;

- time to achieve loading, 10 seconds;

- lubricant, mineral oil M-8V, GOST 10541;
- test time: until the amplitudes of acoustic emission increase more than tenfold, before the initial manifestations of fatigue destruction occur.
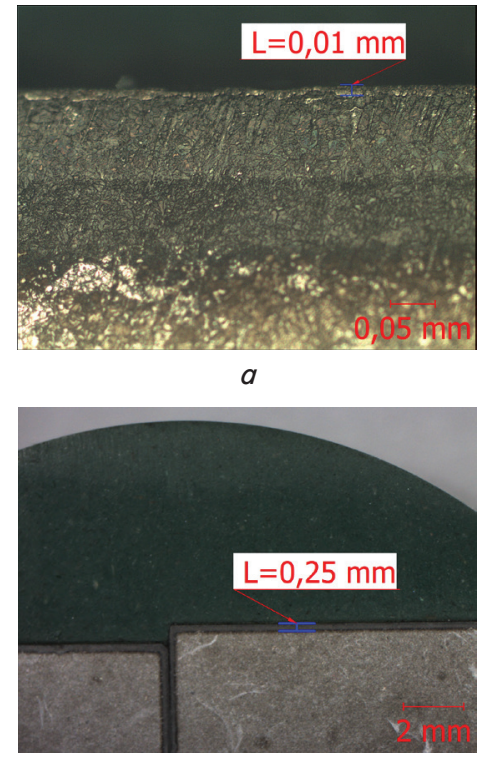

$b$

Fig. 2. The etched thin section of the sample hardened by nitriding: $a-$ microphotograph; $b$ - macrophotograph

Table 1

Microhardness along the cross-section of the cemented layer on samples No. 6C and No. 10C

\begin{tabular}{|c|c|c|c|c|c|c|c|c|c|c|c|c|c|c|}
\hline \multirow[b]{2}{*}{ No. } & \multicolumn{14}{|c|}{ Distance from surface, $\mathrm{mm}$} \\
\hline & 0.1 & 0.2 & 0.3 & 0.4 & 0.5 & 0.6 & 0.7 & 0.8 & 0.9 & 1.0 & 1.1 & 1.2 & 1.3 & $\begin{array}{c}\text { Effective } \\
\text { depth, mm }\end{array}$ \\
\hline \multicolumn{15}{|c|}{ Microhardness, HV } \\
\hline $\begin{array}{c}\text { No. 6C: } \\
1\end{array}$ & 679 & 730 & 731 & 727 & 710 & 697 & 681 & 667 & 652 & 637 & 598 & 528 & 506 & $\sim 1.3$ \\
\hline 2 & 696 & 705 & 689 & 678 & 652 & 628 & 605 & 585 & 581 & 550 & 529 & 510 & 486 & $\sim 1.25$ \\
\hline 3 & 703 & 670 & 657 & 649 & 621 & 597 & 587 & 562 & 554 & 522 & 505 & 486 & 478 & $\sim 1.1$ \\
\hline 4 & 699 & 665 & 635 & 630 & 622 & 611 & 587 & 560 & 544 & 529 & 524 & 510 & & $\sim 1.25$ \\
\hline $\begin{array}{c}\text { No. 10C: } \\
1\end{array}$ & 731 & 725 & 714 & 702 & 666 & 662 & 637 & 609 & 585 & 556 & 543 & 537 & 501 & $\sim 1.3$ \\
\hline 2 & 731 & 716 & 736 & 739 & 694 & 664 & 660 & 637 & 623 & 591 & 558 & 544 & 506 & $\sim 1.3$ \\
\hline 3 & 731 & 743 & 727 & 710 & 670 & 657 & 628 & 598 & 585 & 558 & 544 & 535 & 506 & $\sim 1.3$ \\
\hline 4 & 705 & 745 & 716 & 688 & 657 & 649 & 616 & 593 & 579 & 562 & 541 & 537 & 475 & $\sim 1.25$ \\
\hline
\end{tabular}

Table 2

Microhardness along the cross-section of the nitrided layer on samples No. $1 \mathrm{~A}$ and No. 5A

\begin{tabular}{|c|c|c|c|c|c|}
\hline \multirow{2}{*}{ No. } & \multicolumn{5}{|c|}{ Distance from surface, mm } \\
\cline { 2 - 6 } & 0.05 & 0.1 & 0.15 & 0.2 & Effective depth, mm (500HV) \\
\hline \multicolumn{7}{|c|}{$\begin{array}{c}\text { Microhardness, HV } \\
\text { No. 1A: } \\
1\end{array}$} & 972 & 831 & 741 & 379 & $\sim 0.155$ \\
\hline 2 & 1024 & 876 & 754 & 388 & $\sim 0.155$ \\
\hline 3 & 977 & 892 & 793 & 388 & $\sim 0.155$ \\
\hline 4 & 965 & 783 & 749 & 352 & $\sim 0.155$ \\
\hline $\begin{array}{c}\text { No. 5A: } \\
1\end{array}$ & 932 & 800 & 734 & 420 & $\sim 0.155$ \\
\hline 2 & 918 & 788 & 718 & 374 & $\sim 0.155$ \\
\hline 3 & 930 & 829 & 777 & 421 & $\sim 0.155$ \\
\hline 4 & 927 & 813 & 750 & 420 & $\sim 0.155$ \\
\hline
\end{tabular}




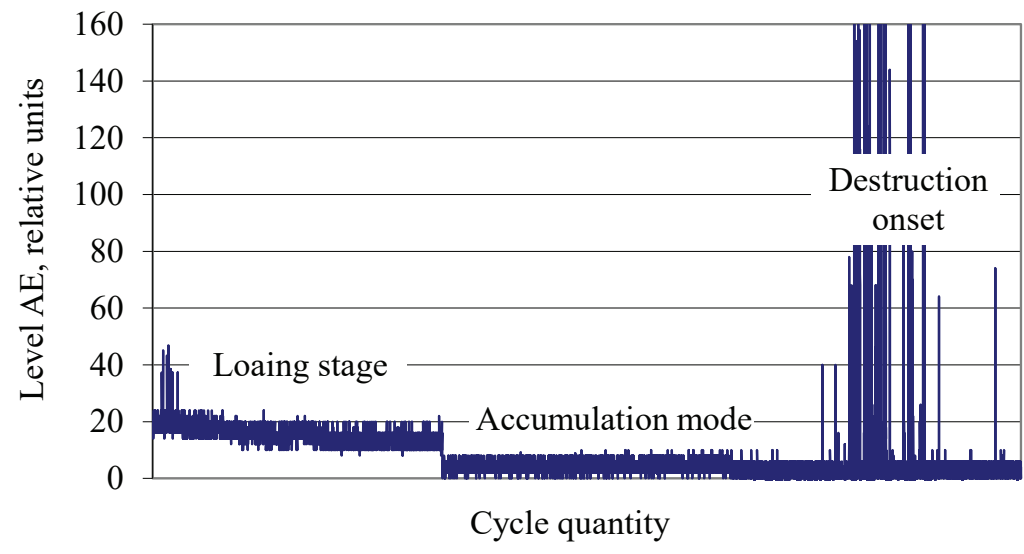

Fig. 3. A pair of $6 \mathrm{C} / 10 \mathrm{C}$ samples. 59,000 cycles before the damage occurs

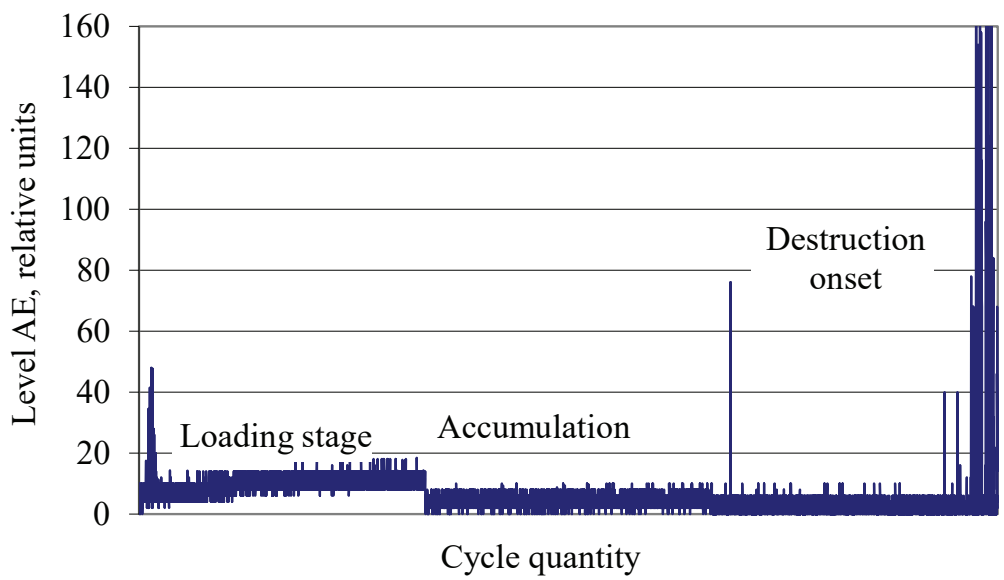

Fig. 4. A pair of $9 \mathrm{~A} / 3 \mathrm{~A}$ samples. 97,500 cycles before the damage occurs

\section{Results of studying the fatigue strength of surfaces hardened by cementation and ion-plasma nitriding}

\section{1. Results of the accelerated tests of examined sam-} ples for fatigue strength

During the tests, it was established that each test cycle consists of three characteristic stages. The first is the loading stage. The second stage is to enter a steady mode of damage accumulation in the surface layer. The third stage is the transition to the initial destruction of a fatigue nature.

Fig. 3, 4 show the diagrams of acoustic emission radiation when testing one of the pairs of samples hardened by cementation and nitriding.

The averaged results for the tribotechnical parameters from testing the pairs of samples for fatigue strength are given in Table 3.

Table 3

Averaged results for tribotechnical parameters from the accelerated tests

\begin{tabular}{|c|c|c|c|c|}
\hline \multicolumn{2}{|c|}{ Sample hardening } & \multicolumn{2}{|c|}{$\begin{array}{c}\text { Friction factor/mean } \\
\text { surface temperature, }{ }^{\circ} \mathrm{C}\end{array}$} & $\begin{array}{c}\text { Cycle quantity be- } \\
\text { fore the manifes- } \\
\text { tation of fatigue } \\
\text { destruction }\end{array}$ \\
\hline Drive & Driven & Test start & Test finish & 53,812 \\
\hline $\begin{array}{c}\text { Cemen- } \\
\text { tation }\end{array}$ & $\begin{array}{c}\text { Cemen- } \\
\text { tation }\end{array}$ & $0.054 / 43$ & $0.045 / 45$ & 97,875 \\
\hline Nitriding & Nitriding & $0.08 / 50$ & $0.063 / 52$ & 9 \\
\hline
\end{tabular}

After tests, we estimated the working surfaces of all samples using binocular and optical microscopes. The images of surface damage after the tests are shown in Fig. 5.

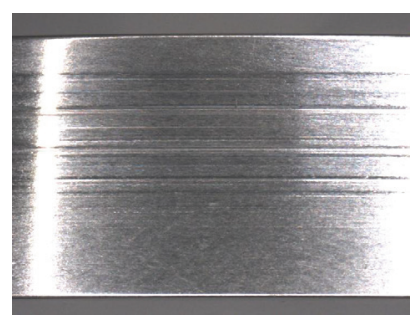

$a$

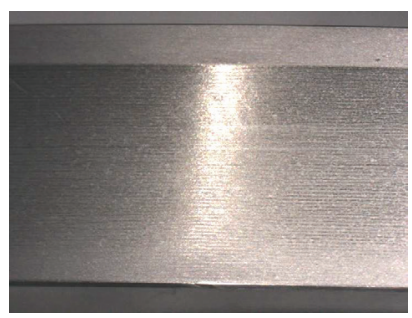

$b$

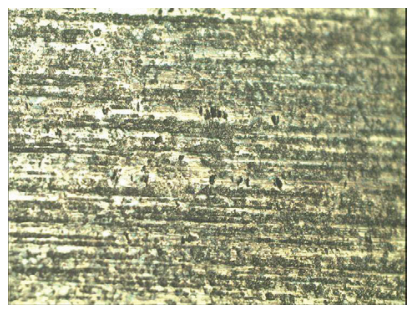

c

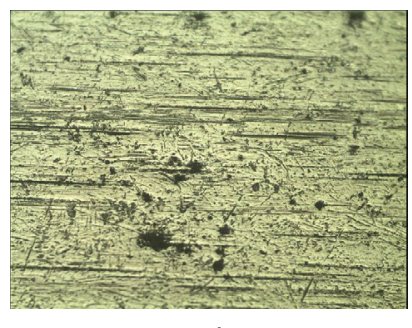

Fig. 5. Image of a sample surface after the tests: $a(\times 6.5), c(\times 100)-$ the surfaces of rollers hardened by cementation; $b(\times 6.5), d(\times 100)-$ the surfaces of rollers hardened by nitriding

It was established that the starting reliefs of the contacting surfaces of all the samples tested are rolled over, except that the contact surfaces of the nitrided samples that were not treated by grinding, the initial relief of the pre-treatment is visible.

The contacting surfaces of the samples demonstrate dashes of different sizes due to the slippage and ingress of particulate matter into the contact area. There are also traces of pressing, characterized by bulging material along the contour, as well as group clusters of traces of pressing of different sizes caused by the crushing of a harder particle. The surfaces of the samples hardened by cementation demonstrate multiple traces of chipping with the presence of adjacent thin ulcer cracks, indicating the fatigue nature of chipping. The surface of the nitrided samples also shows 
numerous traces of chipping of different sizes; however, given the rougher surface relief, ulcer cracks are not visible.

It was found that the contacting surfaces of the driven samples were damaged more intensively than the drive samples, regardless of the technique for their hardening (cementation or nitriding).

Measurements of damage depth at the surface of samples using the interferometer MI-4U4.2 showed that for the cemented surfaces it could, depending on the diameter of the damage, vary between 0.01 and $0.027 \mathrm{~mm}$. For the nitrided surfaces, the depth of damage did not exceed $0.003 \mathrm{~mm}$.

Our comparative tests of the samples hardened by different technologies have demonstrated that at the specific contact load $\sigma=1,140 \mathrm{MPa}$ the working surfaces of all the samples tested showed the initial sites of fatigue chipping. The average number of cycles prior to the initial destruction due to fatigue for samples hardened by the Avinit nitriding technology is 1.82 times higher compared to the samples hardened by conventional gas cementation. This gives reason to conclude that the fatigue characteristics of nitrided samples with a thickness of the hardened layer of $0.25 \mathrm{~mm}$ are higher compared to the cemented samples with the hardened layer's thickness of $1.2 \mathrm{~mm}$.

\section{2. Results of studying the experimental samples for fatigue strength during prolonged tests \\ Tribotechnical results from testing the multicycle resis- tance to fatigue destruction are given in Tables 4, 5 . \\ The test time for each pair of samples is 32 hours. or 960,000 cycles. Each pair of samples, taking into consider- ation the first stage of the accelerated tests, operated over more than $1 \cdot 10^{6}$ cycles. Before these tests, each sample was weighted at the analytical laboratory scales VLA-200 with an accuracy of $110^{-4} \mathrm{~g}$.}

Table 4

Results of measuring the friction and temperature coefficients

\begin{tabular}{|c|c|c|c|c|c|}
\hline \multicolumn{2}{|c|}{ Sample hardening } & \multirow{2}{*}{\multicolumn{4}{|c|}{ Friction factor/mean surface temperature, ${ }^{\circ} \mathrm{C}$}} \\
\hline Drive & Driven & & & & \\
\hline \multicolumn{2}{|c|}{ Cementation } & \multirow{12}{*}{$\begin{array}{c}\text { After } \\
240,000 \\
\text { cycles }\end{array}$} & \multirow{2}{*}{$0.036 / 50.4$} & \multirow{8}{*}{$\begin{array}{c}\text { After } \\
960,000 \\
\text { cycles }\end{array}$} & \multirow{2}{*}{$0.036 / 50.4$} \\
\hline No. $6 \mathrm{C}$ & No. 10C & & & & \\
\hline \multicolumn{2}{|c|}{ Nitriding } & & \multirow{2}{*}{$0.043 / 54.2$} & & \multirow{2}{*}{$0.036 / 50.4$} \\
\hline No. $5 \mathrm{~A}$ & No. $1 \mathrm{~A}$ & & & & \\
\hline \multicolumn{2}{|c|}{ Cementation } & & \multirow{2}{*}{$0.036 / 50.4$} & & \multirow{2}{*}{$0.036 / 50.4$} \\
\hline No. $8 \mathrm{C}$ & No. $2 \mathrm{C}$ & & & & \\
\hline \multicolumn{2}{|c|}{ Nitriding } & & \multirow{2}{*}{$0.043 / 54.2$} & & \multirow{2}{*}{$0.036 / 50.4$} \\
\hline No. $2 \mathrm{~A}$ & No. $10 \mathrm{~A}$ & & & & \\
\hline \multicolumn{2}{|c|}{ Cementation } & & \multirow{2}{*}{$0.036 / 50.4$} & & \multirow{2}{*}{$0.036 / 50.4$} \\
\hline No. 4C & No. 5C & & & & \\
\hline \multicolumn{2}{|c|}{ Nitriding } & & \multirow{2}{*}{$0.043 / 54.2$} & & \multirow{2}{*}{$0.036 / 50.4$} \\
\hline No. 11A & No. 4A & & & & \\
\hline
\end{tabular}

Table 5

Results of determining the weight wear of samples

\begin{tabular}{|c|c|c|c|}
\hline \multirow{2}{*}{ Sample hardening } & \multicolumn{2}{|c|}{ Sample weight wear, g } & \multirow{2}{*}{$\begin{array}{c}\text { Total sam- } \\
\text { ple wear, g }\end{array}$} \\
\cline { 2 - 3 } & Drive & Driven & Mean value \\
\cline { 2 - 3 } Mean value & Mean value & Mean \\
\hline $\begin{array}{c}\text { Cementation No. 6C, } \\
\text { No. 8C, No. 4C }\end{array}$ & 0.1837 & 0.1107 & 0.2944 \\
\hline $\begin{array}{c}\text { Nitriding No. 5A, } \\
\text { No. 2A, No. 11A }\end{array}$ & 0.0171 & 0.0119 & 0.029 \\
\hline
\end{tabular}

No burr phenomena were registered during the entire test period on any pair of the samples.

At the same time, the driven samples wear out less intensely than do the drive ones, by about $30 \%$ for the nitrided samples, and by about $40 \%$ for the cemented samples.

The fundamental difference is the nature of the transition process to change the friction moment after loading.

In the nitrided tribopairs, at each subsequent test cycle, the amount of friction moment after loading is set gradually over 10-12 minutes, that is, the tribopair seems to be adjusting to operation again.

In the cemented tribopairs, at each subsequent test cycle, the amount of friction moment after loading is set immediately.

The working surfaces of all samples demonstrate ring lines:

- multiple - on the cemented samples;

- single, against the trace of operation, on the nitrided samples. At the same time, the samples demonstrate the starting reliefs of pre-machining, performed before the nitriding.

Metallographic studies following the long tests for fatigue strength have revealed that the relief of the smoothed surfaces, typical of the operation at slipping, is accompanied by the formation of surface lines and recesses in the form of point caverns.

Such damage is observed at all the sites participating in the contact.

The caverns are the traces of fatigue exfoliation and chipping: the surfaces of the caverns' bottom there demonstrate the rest lines characteristic of fatigue destruction (Fig. 6, $a, b$ )

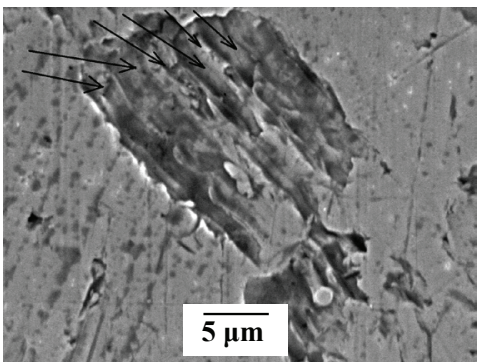

$a$

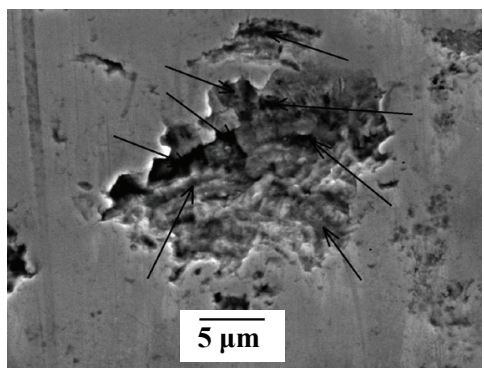

Fig. 6. Results from the fractographic study of the cavern: $a$ - cemented sample; $b$ - nitrided sample

To confirm the hypothesis of the causes of the advantages of structural engineering of the surface at nitriding over the surface at cementation, we measured the microhardness in the depth of the surface layer before the tests and after 32 hours of operation.

In a cemented layer up to $0.2 \mathrm{~mm}$ deep, after $960,000 \mathrm{cy}$ cles, we observed a significant decrease in microhardness. This can be associated with the accumulation in the surface 
layer of fatigue defects at the microstructural level and, consequently, the increased integrated wear amount (conventional mechanochemical wear plus ulcerative destruction). For the nitrided samples, the microhardness values remain at almost the same level as the confirmation of surface layer amorphization, and, consequently, the accumulation of fatigue defects to a much lesser extent.

Thus, the results of our comparative tests evidenced a significant advantage of the samples hardened by the Avinit $\mathrm{N}$ nitriding compared to cementation. The samples that were hardened by the Avinit N technology demonstrate the higher wear resistance indicators, taking into consideration the fatigue mechanism of surface destruction.

\section{Discussion of results of the comparative tribotests of samples hardened by cementation and the ion-plasma nitriding Avinit $\mathbf{N}$}

Our findings suggest that the samples hardened by the Avinit $\mathrm{N}$ technology demonstrate the higher wear resistance rates compared to cementation taking into consideration the fatigue mechanism of surface destruction (Table 5). This can be explained by the presence, among other signs, of chipping along the edge of the working parts of samples exposed to cementation and the practical absence of such a phenomenon in the samples hardened by nitriding.

Resistance to wear by metallic materials is a structurally sensitive characteristic. During the ion-plasma nitriding using the Avinit $\mathrm{N}$ technology, a nitrided layer with fine-grained equilibrium microstructure without a fragile surface structure (Fig. 2) is formed at the surface of an article (Fig. 2), in contrast to the microstructure of the surface layer after cementation (Fig. 1).

One of the factors in increasing the multicycle fatigue is the presence of squeezing residual macro- and micro-stresses in the surface layer. A distinctive feature of the nitrided surface layers, according to [8], is the different behavior of compressive residual macroscopic stresses and the level of residual micro-stresses on the surface during cyclical deformation. Thus, the compressive residual macroscopic stresses of nitrided steels at cyclic deformation are completely relaxed at stresses close to the limit of endurance. The level of the residual micro-stresses on the surface does not change with an increase in the number of load cycles, or even increases due to the deformation cyclic hardening. A similar feature of the nitrided layer, when compared to the cemented one, was confirmed by studies of changes in the microhardness of the surface layer after long tests for fatigue strength reported in this work.

The tribological approach to assessing the quality of the nitrided layer was applied in [9]. The wear tests of the nitrided steel 38X2MUA revealed the presence of four sites on the wear kinetics curves of the main sample and a counter-body as a function of test time, differing in the weight loss amount. Accordingly, these are the sections of the adjusting operation zone, the enhanced wear resistance zone, the high wear resistance zone, and the area of damage manifestations in the form of burrs. The method of acoustic emission in tribological tests has also revealed the presence of different zones during the tests, clearly registering the moment of transition to the stage of fatigue destruction onset (Fig. 3, 4). Unlike wear tests, the acoustic emission method is less time-consuming and faster when registering the moment of the tribosystems' transition from normal wear to initial destruction due to fatigue.

The effectiveness of the nitriding method to increase the contact strength of a surface and its wear resistance depends not only on the choice of the nitriding method and modes. It is important to choose the right steel in terms of its composition and the number of alloying elements in it. The authors of work [9], based on the detected patterns of structure formation at nitriding and the results from mechanical tests, stated the conditions for ensuring high tribotechnical indicators of treated materials, including the choice of materials for nitriding. The steel used in our work, 20X3MVF, corresponds to the characteristics of the materials listed in work [9].

The data reported in the current study confirm the effectiveness of using the nitriding method as a possible alternative to a cementation method, to increase the contact strength of a surface with a proper choice of the technique and modes of nitriding, as well as the material. At the same time, the results in our paper have been obtained only for a specific technology of plasma nitriding, Avinit N, and for a specific material. Therefore, both the choice of the nitriding method and the optimization of nitriding conditions for different materials in order to obtain the maximum possible values of contact strength for different working conditions require further research.

\section{Conclusions}

1. The results of accelerated tests for fatigue strength have shown that the acoustic emission method makes it possible to effectively register the moment of the transition of tribosystems from normal wear to the initial destruction due to fatigue. On average, the pairs of samples, hardened by the Avinit N nitriding technology, demonstrated the resistance to the formation of the initial sites of fatigue chipping, which is 1.82 times higher compared to the samples hardened by conventional gas cementation.

2. The integrated resistance of the nitrided samples against fatigue destruction in the tests based on $10^{6}$ cycles at the contact load $\sigma_{\max }=1,140 \mathrm{MPa}$ is more than 10 times higher than that of the samples hardened by cementation.

\section{References}

1. Fedorov, V. V. (1985). Kinetika povrezhdaemosti i razrusheniya materialov. Tashkent: FAN, 175.

2. Ibatullin, I. D. (2008). Kinetika ustalostnoy povrezhdaemosti i razrusheniya poverhnostnyh sloev. Samara: Samar. gos. tehn. un-t, 387.

3. Arzamasov, B. N., Bratuhin, A. G., Eliseev, Yu. S., Panayoti, T. A. (1999). Ionnaya himiko-termicheskaya obrabotka splavov. Moscow: Izd-vo MGTU im. N.E. Baumana, 400.

4. Zinchenko, V. M., Syropyatov, V. Ya., Prusakov, B. A., Perekatov, Yu. A. (2003). Azotniy potentsial: sovremennoe sostoyanie problemy i kontseptsiya razvitiya. Moscow: FGUP «Izdatel'stvo «Mashinostroenie», 90.

5. Kaplun, V. G., Kaplun, P. V. (2015). Ionnoe azotirovanie v bezvodorodnyh sredah. Hmel'nits'kiy: HNU, 318. 
6. Wu, Y. S., Ma, B. T., He(HO), J. W., Luo, B. Z. (1989). A criterion for contact fatigue of ion-nitrided gear. Wear, 129 (1), 13-21. doi: https://doi.org/10.1016/0043-1648(89)90275-5

7. Boniardi, M., D’Errico, F., Tagliabue, C. (2006). Influence of carburizing and nitriding on failure of gears - A case study. Engineering Failure Analysis, 13 (3), 312-339. doi: https://doi.org/10.1016/j.engfailanal.2005.02.021

8. Terent'ev, V. F., Michugina, M. S., Kolmakov, A. G., Kvedaras, V., Čiuplys, V., Čiuplys, A., Vilys, J. (2007). The effect of nitriding on fatigue strength of structural alloys. MECHANIKA, 2 (64), 12-22.

9. Gerasimov, S. A., Kuksenova, L. I., Alekseeva, M. S. (2017). Peculiarities of structure and tribological properties formation of the nitrided steel and alloy. Bulletin of Science and Technical Development, 7 (119), 3-17.

10. Conrado, E., Gorla, C., Davoli, P., Boniardi, M. (2017). A comparison of bending fatigue strength of carburized and nitrided gears for industrial applications. Engineering Failure Analysis, 78, 41-54. doi: https://doi.org/10.1016/j.engfailanal.2017.03.006

11. Kaplun, P. V., Gonchar, V. A. (2015). Effect on durability ion nitriding open gears. Problems of Tribology, 2, 84-89.

12. Kaplun, P. V., Honchar, V. A., Donchennko, T. V., Matviichin, P. V. (2019). Nfluence of ionic nitriding and remainingaustenite on longevity permanent at friction woobling. Herald of Khmelnytskyi national university, 1, 122-129. Available at: http://elar.khnu.km.ua/ jspui/handle/123456789/7581

13. Shetty, K., Kumar, S., Raghothama Rao, P. (2009). Effect of ion nitriding on the microstructure and properties of Maraging steel (250 Grade). Surface and Coatings Technology, 203 (10-11), 1530-1536. doi: https://doi.org/10.1016/j.surfcoat.2008.11.034

14. Sirin, S. Y., Sirin, K., Kaluc, E. (2008). Effect of the ion nitriding surface hardening process on fatigue behavior of AISI 4340 steel. Materials Characterization, 59 (4), 351-358. doi: https://doi.org/10.1016/j.matchar.2007.01.019

15. Rolinski, E., Damirgi, T., Woods, M. S. (2015). Ion Nitriding of Ferrous and Titanium Alloys for Gear Applications. Thermal Processing, 36-40.

16. Fomina, L. P, Krymov, V. V. (2016). Sovershenstvovanie tehnologiy uprochneniya zubchatyh koles aviadvigateley. Dvigatel', 2 (104), 6-8.

17. Sahalovych, O. V., Sahalovych, V. V. (2013). Pat. No. 84664 UA. Sposib ionno-plazmovoho pretsyziynoho azotuvannia poverkhon stalei i splaviv Avinit N. No. u201305770; declareted: 16.08.2013; published: 25.10.2013, Bul. No. 23.

18. Sahalovych, O. V., Sahalovych, V. V. (2013). Pat. No. 107408 UA. Sposib ionno-plazmovoho pretsyziynoho azotuvannia poverkhon detali zi stalei i splaviv avinit N. No. a201305768; declareted: 07.05.13; published: 25.12.2014, Bul. No. 24.

19. Filonenko, S. F., Stadnichenko, V. N. (2007). Avtomatizatsiya issledovaniy protsessov samoorganizatsii tribosistem. Avtomatika. Avtomatizatsiya. Elektrotehnicheskie kompleksy i sistemy, 1 (18), 164-167.

20. Stadnychenko, M. H., Dzhus, R. M., Troshyn, O. M. (2004). Pro hranytsi zastosuvannia metodu akustychnoi emisiyi pry vyrishenni zadach trybodiahnostyky. Zbirnyk naukovykh prats XI VPS, 1 (10), 187-195. 